\title{
- ENGLISH WEAK FORMS - A CHALLENGE FOR BULGARIAN LEARNERS OF ENGLISH? A PEDAGOGICAL PERSPECTIVE
}

\author{
NIKOLETA STOYKOVA ${ }^{1}$ \\ Sofia University "St. Kliment Ohridski"
}

Cilj ovog istraživanja jeste da utvrdi da li bugarskim učenicima engleskog usvajanje i tačna produkcija redukovanih formi u engleskim funkcionalnim rečima predstavljaju problem. Takođe se obraća pažnja na to kako bugarski učenici koriste slabe oblike u vezi sa rasporedom naglašenih slogova u toku govora na engleskom u poređenju sa rasporedom slabih oblika i naglašenih slogova u govoru izvornih govornika. Istraživanje se oslanja na empirijske podatke sakupljene tokom časova sa homogenom grupom od 20 bugarskih učenika engleskog koji su studenti prve godine Engleskih i američkih studija na Sofijskom univerzitetu „Sv. Kliment Ohridski”. Ispituje se njihova produkcija slabih oblika u poznatom pasusu vezanog teksta koji sadrži dovoljan broj reči koje obično imaju slabe oblike. Svi učesnici su učili engleski kao strani jezik 4 ili više godina. Usvajanje i produkcija engleskih slabih oblika je problematična oblast za izvorne govornike bugarskog i njihova percepcija i produkcija zahtevaju dalje ispitivanje.

Ključne reči: engleski, bugarski, slabi oblici, naglašenost, L2 učenici, produkcija.

\section{INTRODUCTION}

When learning a foreign language, the majority of students strive to achieve fluency, while a substantial part also aim at native-like proficiency in it. The latter try to adopt as many new items from the vocabulary stock, and grammatical structures from the foreign language, as possible. They try to imitate the way other people talk, behave and act. However, achieving a native-like proficiency in a foreign language is a daunting task, especially because apart from lexis and grammar, there come the phonetics and phonology of the foreign language as well. Actually, phonetics and phonology play quite a significant role in achieving a certain degree of fluency and many aspects of phonetics

1 Contact information: stoykova.n@gmail.com 
and phonology have appeared to be quite difficult for students to master (Flege 1995: 266, Best and Tyler 2007: 16). In the specific case of Bulgarian learners of English, we can also talk about the transfer of L1 features to the L2 (Danchev 1988: 96). In my capacity as an assistant lecturer teaching the course of Practical Phonetics to first year students at Sofia University "St. Kliment Ohridski" for the past 3 years now, at the beginning of every year I start the course by asking the students to fill in a short questionnaire. I then analyse it and see what their expectations are, and most importantly, I gather information whether they have a preferred/least liked/unintelligible accent, whether they have previously been taught phonetics or any aspect of phonetics, etc. Some of the answers to the questions gave rise to some ideas for research. I am going to summarize some data from 30 questionnaires which I have taken into account. All of the students are in their first year of studying English philology and are between 19 and 21 years of age. Since some of them had not indicated their gender, and since it is not relevant for drawing conclusions from this exact questionnaire, I will not consider it as an important feature. The more valuable part comes from the answers to some of the questions given by these 30 students. All of the questions were of the open type and the students could write as much as they thought necessary. $60 \%$ of them have indicated that they haven't been taught anything about phonetics before, $27 \%$ admit they have never used the pronunciation section of a dictionary, and $60 \%$ indicate that speaking a foreign language in front of other people, especially natives, makes them uncomfortable and they feel anxious. 53\% of the students share that they have never been misunderstood by other people due to their pronunciation, while $20 \%$ say maybe. Then, the interesting bit comes, where as an answer to the $9^{\text {th }}$ question $100 \%$ of the students ascertain that their pronunciation needs to be improved, and as aspects that need to be worked on, they point at individual sounds, specific words, stress, rhythm, and intonation. One of the reasons given was "to avoid sounding too foreign". This makes me draw two conclusions - first, that my students are self-conscious of their pronunciation and they know they need to work on it, and second, that I will have to help them overcome to some extent the fear of speaking English and teach them how to lose their "foreign" accent as much as possible.

English weak forms are a challenging field for research, especially when it comes to their production and perception by non-native learners. According to some of my students weak forms sound "weird" and "indolent", and their users are "sloppy". During my rather short experience of three years of teaching at university, $90 \%$ of all my students were surprised to find out that such forms even existed. However, since Ladefoged and Johnson note that:

"There is, of course, nothing slovenly or lazy about using weak forms. [...] Rather than being labeled lazy, it could be described as being more efficient, in that it conveys the same meaning with less effort. Weak forms and assimilations are common in the speech of every sort of speaker in both Britain and America. Foreigners who make insufficient use of them sound stilted." (Ladefoged and Johnson 2011: 111), it seems that weak forms sound unnatural not only to Bulgarian but to other non-native speakers and learners as well.

As Cruttenden (2014: 321) notes, a foreign language is learnt via words in isolation, pronounced in their citation forms, while in real life connected speech, these same words 
undergo slight changes that the non-native speakers need to be aware of, incorporate in their own speech styles and resort to using eventually. Giegerich (1992: 249) also states that "Citation forms are a form of speech that is, to say the least, somewhat idealised". In addition to that, Danchev (1988: 102) rightly observes that learning a foreign language without proper study of its phonetic features at the beginning of a language course will lead to more long-lasting pronunciation errors in comparison with a course that covers those features in some detail. Weak forms are an inseparable part of the speech habits of English speakers and as such they have to be acquired by non-native speakers. By acquisition I mean that they have to be able to both perceive and produce them correctly. According to another scholar, Kelly (2002: 75), "it is important that learners are taught the possible forms of these words when they are introduced because they should be given the opportunity of becoming attuned to them" and "native speakers tend not to notice features of connected speech when they are used, but do notice when they are not". When it comes to reasons why it is vital for students to learn how and when weak forms are used, Roach (2009: 89) gives two main ones: the first one is that native English speakers consider an "'"all-strong form" pronunciation unnatural and foreign-sounding" and the second is that "speakers who are not familiar with the use of weak forms are likely to have difficulty understanding speakers who do use weak forms; since practically all native speakers of British English use them, learners of the language need to learn about these weak forms to help them to understand what they hear."

The most extensive work on weak forms that I have come across so far belongs to Obendorfer. He presents a list of about 100 words and provides a full definition of weak forms (Obendorfer 1998: 28):

(1) weak forms are paradigmatically non-basic phonological word forms, or parts of word forms.

(2) they represent morphosyntactic words in certain non-prominent contexts.

(3) their phonological shape is semi-reduced, reduced or cliticized.

(4) they are the products of an ultimately idiosyncratic process.

He also divides them into four major classes (Obendorfer 1998: 46): absolute (than; that), normal (at; can), occasional (any; so), and marginal weakeners (this; no), noting also that "differences in weakening potential are scalar rather than categorical". However, he claims that absolute and normal weakeners are the ones that have high frequency of occurrence in the spoken language (Obendorfer 1998: 72).

\section{MATERIALS AND METHODS}

20 first-year students in English and American Studies at Sofia University "St. Kliment Ohridski" were recorded for this production task. All of them have just graduated from high school. I have analysed 20 student recordings, 5 belonging to male and 15 to female speakers. All of the participants are native speakers of Bulgarian with 5 or more years of English language learning experience, being at B2/C1 level according to the European Framework of Reference for Languages: Learning, Teaching, Assessment (CEFR). The students' age is between 19 and 21, the majority of them being 19 and 
20 years old. I have not taken into consideration their respective hometowns since this characteristic is not relevant to the current study. The recordings were made in a phonetic classroom with the Audacity software, using the equipment available in the room - a standard headset with a microphone and a computer with a Windows 10 operating system. The produced sound files were saved in .wav format.

The subjects were asked to read a short connected speech passage. They were given instructions to read a short text first in order to get better acquainted with it, and then read it aloud in their preferred accent (which was predominantly RP). Each student was given enough time to study the text in advance and then read it out loud. None of the students were told what the connected speech passage was going to test in order to avoid any bias and unnecessary pressure on their side. The subjects had to click on the "record" button to start and on the "stop" button to finish the recording, then save it as a sound file in the .wav format with their name as the file name. After clicking on the stop button, they could listen to their own recordings but were not allowed to repeat the recording.

For the production task, which was the basis for the judgement task, I had chosen the very well-known connected speech passage "The North Wind and the Sun". It serves the purpose of this investigation perfectly well, since it contains 19 words which are expected to appear in their weak forms, and these have 47 occurrences in different environments throughout the whole text. The function word that occurs in the largest number of instances is the definite article "the". None of the function words from the passage is expected to be pronounced in its strong, full form. The list of words which are expected to appear in their reduced forms in the text is the following: (in alphabetical order) $a$, and, as, at, be, but, could, he, him, his, of, should, than, that, the, to, was, were, who.

The sole judge of the recorded items was the author of this paper, a native speaker of Bulgarian.

\section{ANALYSIS AND RESULTS}

The data were analyzed auditorily by counting the wrongly produced instances of the function word items, where the weak forms of English grammatical words were expected to occur. These were then converted to simple percentages. The recordings were checked multiple times in order to detect and note incorrect rendering of weak forms as their strong form counterparts. For reference and guidance, I used the lists of Roach (2009: 90-95), Dimitrova (2003: 59), and Obendorfer (1998: 206-210), as well as a recording made by a native English speaker. Two additional judges were also asked to check the unclear instances of function words in 6 independent cases. These included the pronunciation of "was" by 3 speakers. The whole text of "The North Wind and the Sun" consists of 113 words in total, 47 of which are expected to be uttered in their weak forms. These 47 words constitute $41.6 \%$ of all words, and 7 out of these 47 instances (or $15 \%$ of them) were pronounced without a mistake by all 20 speakers. 12 instances, or $25.5 \%$ of the 47 weak form instances, were pronounced incorrectly by 4 speakers (the majority of the incorrect productions were made by one and the same speaker -9). The 
words that have more than 4 wrong productions represent $46.8 \%$ of all 47 expected weak form words, while the total of wrong productions amounts to $85 \%$ of all expected weak forms in the text.

The weak forms pronounced incorrectly as strong forms by all 20 speakers were: one instance of and, one instance of he, and should. I have to make a note that should is present only once in the text, while he is encountered twice, and the occurrences of and are four in number. What is interesting to note is that when it comes to the other 3 instances of and 17, 19 and 19 out of the 20 speakers produced its strong form, and when it comes to the other instance of he, again only one speaker used the weak form - what these show is that the speakers are inconsistent in their usage of weak forms. Since 2 out of the 3 top mispronounced words have other instances throughout the text, we will look at them more closely. Thus, we note inconsistency on the part of the speakers because Speaker 1 produced two reduced and two strong forms for the 4 different instances of and. Speakers 3 and 4 similarly produced 1 reduced and 3 strong forms of the same word.

When we take into account the words he(x2), him, his( $\mathrm{x} 3)$, we again note inconsistencies in the production. As mentioned above, speakers 3 and 4 have reduced only one of the instances of his, while speaker 1 has not reduced the form of he only, having produced the rest of the function words in their reduced forms.

To sum up, when we look at the overall performance of the students and their pronunciation of weak forms, we will have to note the following: the speakers with the lowest percentage of incorrect production of weak forms are Speaker 1 (23.4\%), followed by Speakers 3 and 4 with $27.7 \%$ and 30\% respectively. The speakers who have the highest percentage of incorrectly produced weak forms are Speaker 7 (62\%) and Speaker 10 (51\%). The rest of the subjects (15 students) show results which range between $32-47 \%$.

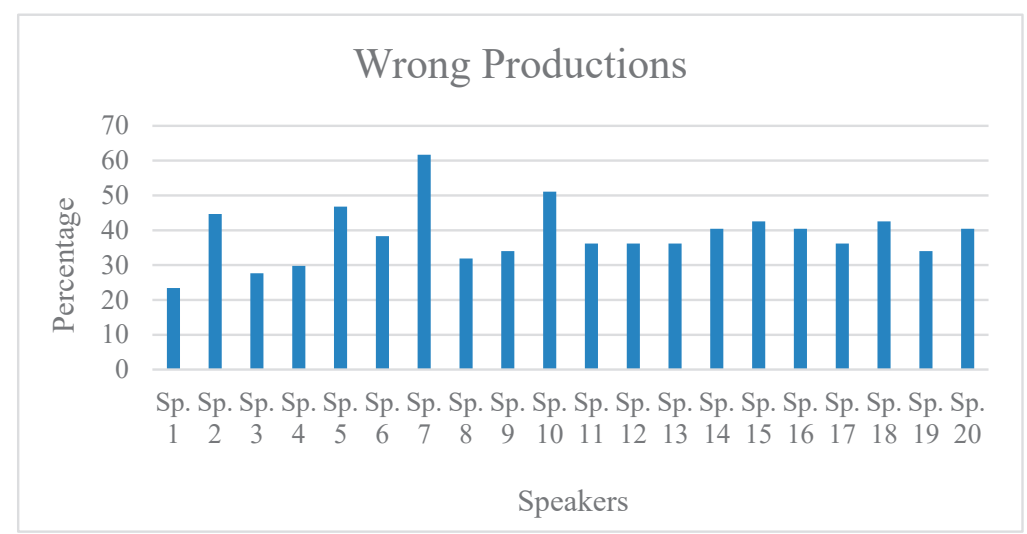

Table 1. Wrong productions by all speakers

Lastly, I would like to touch upon two function words that are a part of the text the one that is encountered the most throughout, namely the definite article the, and 
the other one that has only one instance - the particle to. Both words have two weak forms and the use of either depends on the sound that comes next. For the there are the variants [ðə] in front of consonants and [ði] in front of vowels. For to, we have [tə] in front of consonants and [tu] in front of vowels. Regarding the pronunciation of to in "to confess" only 3 out of the 20 speakers produced the correct weak form in front of a consonant. As to the production of the weak forms of the, the results are more complex. There are only two instances in the text, where the weak form in front of vowels [ði] has to be used - in "the other" and in "the attempt". In the first instance of the weak form of the in the text in front of a vowel, namely in "the other", six speakers wrongly produced the weak form that occurs before consonants. In the second instance - in "the attempt", there were 12 speakers who produced it the wrong way. Four of these 12 speakers produced the weak form of the in both "the other" and "the attempt" as [ðə] instead of [ði]. As to the pronunciation of the as [ðə] in front of consonants, 10 of its instances were pronounced wrong as [ði] by one and the same speaker, while four other speakers produced only one of its instances incorrectly. This suggests that the speaker who produced the biggest number of these incorrect weak forms is not aware either of the specific requirements for the pronunciation of the weak forms of the, or of the existence of weak forms in general.

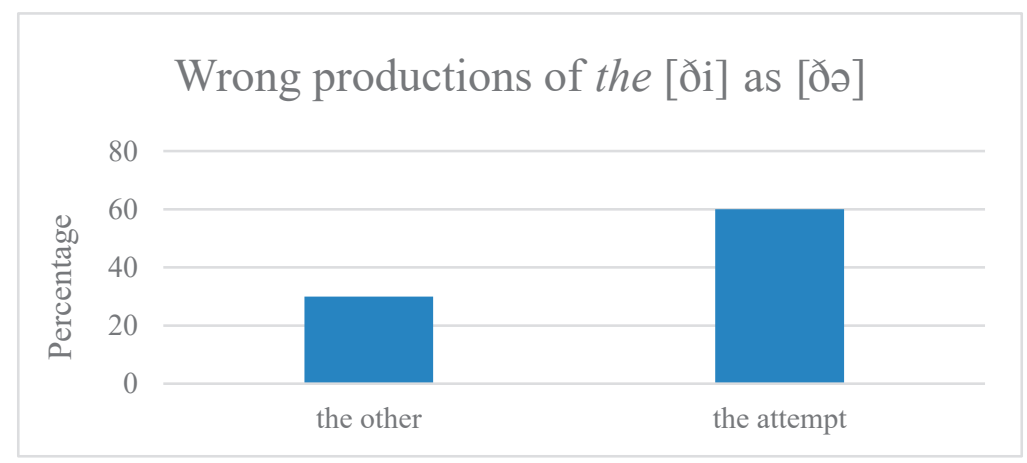

Table 2. Wrong productions of the [ði] as [ðə]

\section{DISCUSSION AND CONCLUSIONS}

The research reported here had as its aim to answer the question whether it is problematic for Bulgarian language learners of English to acquire and produce the reduced forms of English function words correctly.

This study was conducted before all first-year students were explicitly taught a lesson on English weak and strong forms. It was carried out this way, so that their prior knowledge of the topic could be evaluated. Since weak and strong forms are supposed to be taught at secondary level, undergraduates are expected to be aware of their existence and use. What is more, in the questionnaire that I conduct at the beginning of every school year, a number of students admit to having had multiple contacts with native speakers of English, which means that they have been exposed to the native speakers' speech. Taking into consideration all of the above, students, and 
the participants in the study in particular, are expected to have a certain amount of knowledge regarding the use of weak and strong forms. However, what also becomes clear from the answers to the questionnaire, is that phonetic instruction at secondary level is cut to a bare minimum. This means that students are not familiar with a number of phonetic aspects, one of which is the issue in question. The results from the current study could serve as a more effective starting point in preparing and teaching lessons on English weak and strong forms to Bulgarian learners of English at tertiary level, thus helping instructors in their practical work.

What became clear to me after conducting the experiment is that the subjects rarely incorporate weak forms in their production task. What they tend to do is use the strong forms instead, or use the wrong variant of the weak form. What is more, for words such as and and that I heard quite a lot of variation in the production of strong forms, too. Some speakers pronounced and as /end/ or /æn/, and a few other speakers produced that as / ðet/ or /ðæ:t/. This finding goes in tune with the observation that "not only weak forms but strong forms as well vary a great deal in connected speech" made by Makino (2012: 70).

What also became evident for me is that Bulgarian learners incorporate strong forms in places where it is natural for a native speaker to use a weak form instead. Insufficient knowledge, fear not to be misunderstood, and an attempt to blend in and not stand out as a foreigner might be pointed out as some of the reasons for the subjects' use of strong instead of weak forms. In other words, in their wish to drop, they enhance their foreignness instead. Also, the fact that English is defined as a stress-timed language, and Bulgarian as possessing features of both stress- and syllable-timed languages might provide an explanation as to why the distribution of stresses in the flow of the students' Bulgarian English speech is different and sounds chunkier compared to the distribution of stresses and weak forms in the speech of a native English speaker.

This experiment is quite small in scale, and additional follow-up experiments and further in-depth analysis will be needed to verify the present results. However, the current investigation served its purpose in answering the question whether English weak forms present a challenge for Bulgarian learners of the language. The answer is a definite yes, and indicates that their production, as well as perception, will need further research.

\section{REFERENCES}

Best, C. T. and M. D. Tyler. 2007. Nonnative and second-language speech perception: Commonalities and complementarities. In M. J. Munro \& 0.-S. Bohn (eds.) Language Experience in Second Language Speech Learning: In honor of James Emil Flege. Amsterdam: John Benjamins, 13-34.

Cruttenden, A. 2014. Gimson's Pronunciation of English. 8th edition. Oxon: Routledge.

Danchev, A. 1988. Kam opisanieto na "balgarskiya anglijski mezhdinen ezik," (Towards the description of the Bulgarian English interlanguage). In S. Peycheva (ed.) Problemi na ovladyavaneto na chuzhd ezik (Problems of foreign language acquisition). Sofia: Narodna Prosveta, 93-109.

Dimitrova, S. 2003. English Pronunciation for Bulgarians. Sofia: Vezni-4.

Flege, J. E. 1995. Second language speech learning: Theory, findings and problems. In W. 
Strange (ed.) Speech Perception and Linguistic Experience: Theoretical and Methodological Issues in Cross-Language Speech Research. Timonium: York Press, 233-272.

Giegerich, H. J. 1992. English phonology: An introduction. Cambridge: Cambridge University Press.

Kelly, G. 2000. How to teach pronunciation. Edinburgh: Pearson Education Limited.

Ladefoged, P. and K. Johnson. 2011. A Course in Phonetics. $6^{\text {th }}$ edition. Wadsworth: Cengage Learning.

Makino, T. 2012. Pronunciations in connected speech: a survey of weak forms in a spoken corpus of American English. In T. Paunović \& B. Čubrović (eds.) Exploring English Phonetics. Newcastle Upon Tyne: Cambridge Scholars Publishing, 57-71.

Obendorfer, R. 1998. Weak Forms in Present-Day English. Oslo: Novus Press.

Roach, P. 2009. English Phonetics and Phonology: A Practical Course. $4^{\text {th }}$ edition. Cambridge: Cambridge University Press.

\section{SUMMARY}

\section{ENGLISH WEAK FORMS - A CHALLENGE FOR BULGARIAN LEARNERS OF ENGLISH? A PEDAGOGICAL PERSPECTIVE}

The aim of thisstudy is to determine whether it is problematic for Bulgarian language learners of English to acquire and produce the reduced forms of English function words correctly. What I also note is how Bulgarian learners incorporate weak forms in relation to the distribution of stresses in the flow of their Bulgarian English speech compared to the distribution of stresses and weak forms in the speech of a native English speaker. The study relies on empirical evidence collected in a class environment from a homogenous group of 20 Bulgarian learners of English, who are first-year university students in English and American Studies at Sofia University "St. Kliment Ohridski". I investigate their production of weak forms in a very well-known connected speech diagnostic passage which contains a sufficient number of common weak form words. All of the participants have been studying English as a foreign language for 4 or more years. The acquisition and the production of English weak forms is a problematic area for native speakers of Bulgarian and their perception and production need further investigation.

KEYWORDS: English, Bulgarian, weak forms, stress, L2 learners, production.

ARTICLE INFO: Original research article Received: June 14, 2018 Revised: December 1, 2018 Accepted: December 6, 2018 